\title{
Simulasi Pengaturan Kecepatan Motor BLDC menggunakan Software PSIM
}

\author{
MUHAMMAD HAMZAH ABDURRAHMAN AS-SALAF, SYAHRIAL
}

Teknik Elektro Institut Teknologi Nasional Bandung, Indonesia

Email: hamzah.sensasi@gmail.com

Received 25 April 2021 | Revised 10 Mei 2021 | Accepted 29 Juni 2021

\begin{abstract}
ABSTRAK
Krisis bahan bakar fosil menjadi salah satu alasan pengembangan teknologi dalam bidang transportasi contohnya kereta listrik dan mobil listrik. Salah satu penggerak yang saat ini banyak digunakan pada kendaraan listrik adalah motor brushless DC (BLDC) yang memiliki efisiensi tinggi, hemat biaya perawatan dan pengaturan yang mudah. Pada umumnya penelitian yang dilakukan terkait dengan motor BLDC adalah tentang pengaturan kecepatan motor, pembebanan pada motor dan yang lainnya. Penelitian ini melakukan simulasi cara pengaturan kecepatan motor BLDC dengan beban yang diubah-ubah dengan menggunakan software PSIM (Power Simulator). Data yang diperoleh melalui simulasi dengan memberikan beban maksimum sebesar $20 \mathrm{Nm}$ dan hasil perhitungan menunjukan bahwa motor BLDC dengan spesifikasi yang digunakan dapat berputar dengan baik pada kecepatan 1442,05 rpm dengan efisiensi sebesar $81,25 \%$. Jika beban yang diberikan pada motor BLDC dinaikan menjadi $30 \mathrm{Nm}$ maka kecepatan motor akan mengalami penurunan menjadi 1221,51 rpm dan efisiensi menjadi $78,34 \%$.
\end{abstract}

Kata kunci: motor BLDC, Kecepatan motor, Beban, efisiensi

\begin{abstract}
The fossil fuel crisis is one of the reasons for the development of technology in transportation, for example electric trains and electric cars. One of the movers that are currently widely used in electric vehicles is the brushless DC motor (BLDC) because this motor has advantages including high efficiency, saving maintenance costs and easy setting. In general, research conducted related to $B L D C$ motors is about regulating BLDC motor speed, loading on BLDC motors and others. In this study a simulation was conducted discussing how to regulate BLDC motor speed with a load that was changed by using PSIM (pow3er simulator) software. From the data obtained through simulation by giving a maximum load of $20 \mathrm{Nm}$ and the calculation results show that the BLDC motor with the specifications used can rotate well at speeds of $1442.05 \mathrm{rpm}$ with an efficiency of $81.25 \%$. If the load given to the BLDC motor is increased to $30 \mathrm{Nm}$, the motor speed will decrease to $1221.51 \mathrm{rpm}$ and the efficiency decrease to $78.34 \%$.
\end{abstract}

Keywords: Brushless DC, speed of motor, load, efficiency

MIND - 103 


\section{PENDAHULUAN}

Saat ini krisis bahan bakar fosil menjadi salah satu asalan pengembangan teknologi dalam bidang transportasi yang paling banyak menggunakan bahan bakar fosil. Contohnya mobil, motor dan kereta api adalah transportasi yang menggunakan bahan bakar fosil. Saat ini motor BLDC adalah motor yang banyak digunakan sebagai penggerak karena motor ini memiliki kelebihan diantaranya efisiensi tinggi, hemat biaya perawatan dan pengaturan yang mudah.

Motor DC yang menggunakan sikat seringkali menimbulkan masalah yaitu ausnya 'sikat' dan timbulnya electrical noise. Oleh karena itu dikembangkan motor DC tanpa sikat atau motor BLDC (brushless direct current) yang mempunyai kelebihan yaitu, efisiensi tinggi, umur yang panjang, konsumsi energi yang kecil dan tidak menimbulkan electrical noise (Djodi, 2012).

Penggunaan motor BLDC untuk kendaraan listrik, peralatan industri dan banyak aplikasi lainnya sudah banyak digunakan karena motor BLDC hampir sama karakteristiknya dengan motor DC tetapi tidak menggunakan sikat untuk dapat beroperasi, sehingga tidak membutuhkan biaya perawatan yang tinggi (Chandra, 2018).

Banyak faktor dalam pemilahan motor yang akan digunakan. Contohnya adalah biaya, jumlah daya yang dibutuhkan dan berapa lama waktu pemakaiannya. Motor BLDC adalah salah satu jenis Motor DC yang tepat untuk digunakan dalam jangka waktu yang panjang (Eclesia, 2013)

motor BLDC adalah motor sinkron dengan magnet permanen yang menggunakan sensor posisi dan sebuah rangkaian elektronika (inverter) untuk mengendalikan arus armature yang ada. Motor BLDC kadangkala dimodelkan sebagai suatu motor DC 2 arah karena armature nya ada di stator dan magnet berada pada rotor dan karakteristik operasinya mirip dengan motor DC. Daripada menggunakan suatu komutator mekanik seperti yang ada pada motor dc konvensional, motor BLDC mengunakan komutasi elektronik yang menjadikannya motor yang minim perawatan (Azzumar, 2012).

Beberapa kelebihan dan kelemahan motor BLDC dibandingkan dengan motor DC dan motor induksi adalah, motor BLDC mempunayi tingkat kebisingan yang rendah saat berputar, karakteristik kecepatan dan juga memiliki torsi yang lebih rendah dibandingkan dengan motor DC maupun motor induksi, umur pakai yang lebih lama dan efisiensi yang tinggi. Sedangkan kelemahan motor BLDC adalah pengendalian kecepatan yang lebih rumit dan harga dari motor BLDC lebih mahal dibanding motor DC dan motor induksi (Gifary, 2017).

Penelitian ini membahas tentang pengaturan kecepatan motor BLDC dengan menggunakan inverter 3 fasa sebagai pensaklaran yang dikendalikan secara digital oleh mikrokontrol, dan diatur dengan menggunakan sinyal PWM (Pulse-Width Modulation) dengan duty cycle variable yang dihasilkan oleh mikrokontrol sebagai pengaturan kecepatan pada motor BLDC. Serta dengan ditambahkannya beban maka dapat dilihat perubahan kecepatan pada motor BLDC dan dapat diketahui juga perubahan efisiensi dari motor BLDC tersebut.

\section{METODE PENELITIAN}

\subsection{Diagram Alir Penelitian}

Gambar 1 menjelaskan tentang proses pengambilan data sampai analisis simulasi pengaturan kecepatan motor BLDC. Simulasi pada kerja praktek ini menggunakan software 
PSIM yang kemudian digunakan beberapa elemen termasuk motor BLDC agar simulasi berjalan dengan baik.

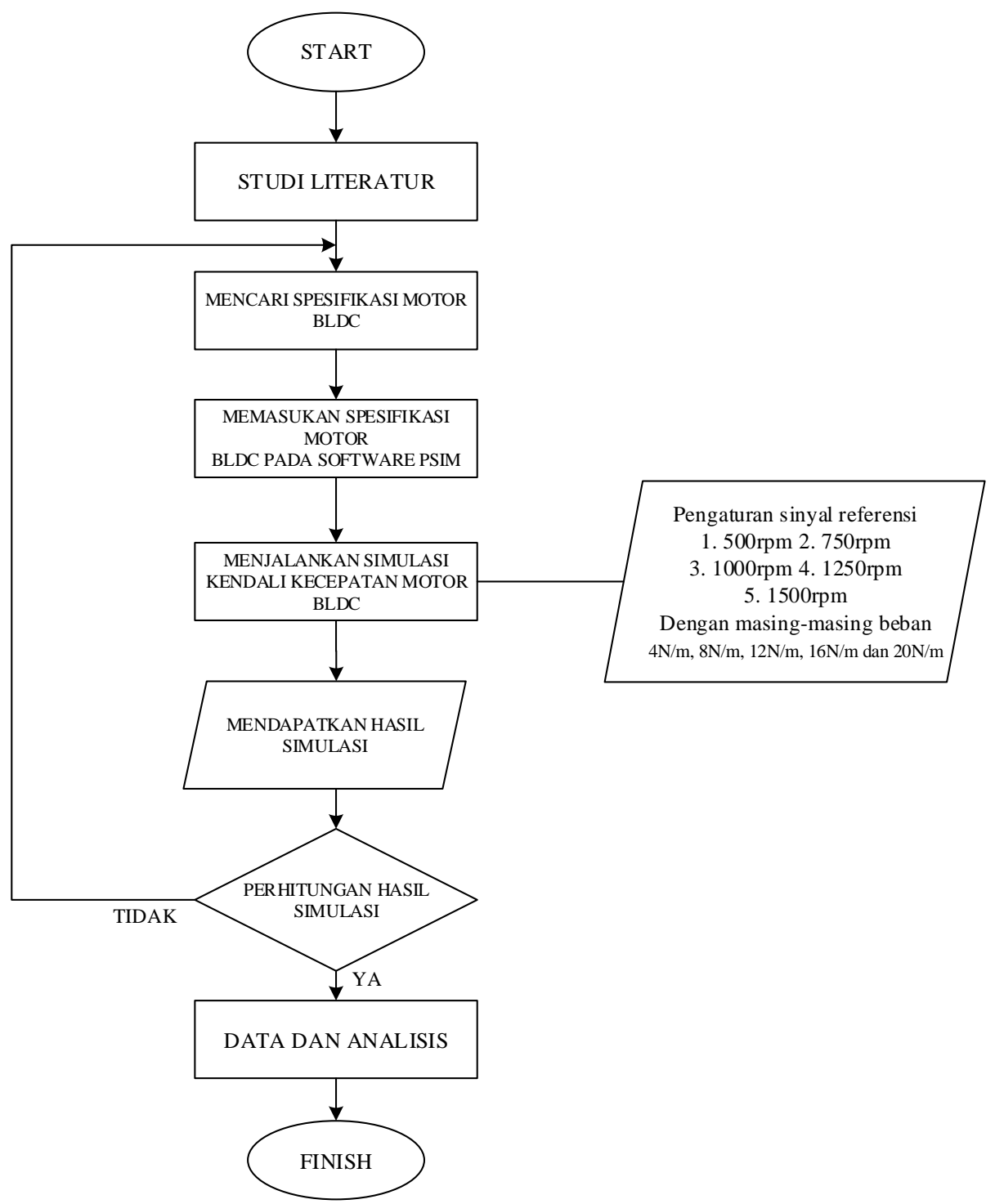

Gambar 1. Diagram Alir Penelitian

Pada makalah ini penulis akan membahas tentang pengaturan kecepatan motor BLDC menggunakan sinyal PWM dan melihat perubahan kecepatan motor BLDC dengan beban yang berubah - ubah. Dan pada penelitian ini diperlukan beberapa teori pendukung diantaranya sebagai berikut :

\subsection{PSIM (Power Simulator)}

PSIM adalah sebuah perangkat lunak komputer yang digunakan merancang dan mensimulasikan berbagai macam rangkaian power elektronik dan motor kontrol. PSIM menyediakan system simulasi yang tepat untuk menganalisa power converter, perancangan kontrol loop dan sistem motor kendali (Ali, 2021).

Pada Gambar 2 Simulasi PSIM terdiri dari tiga program circuit schematic editor (SIM CAD*), PSIM simulator dan waveform processing program SIMVIEW* 


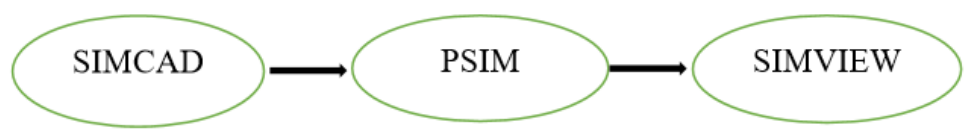

\section{Gambar 2. Diagram Kerja PSIM}

Secara garis besar untuk simulasi menggunakan PSIM pada penelitian ini ditunjukan pada gambar 3. Sistem terdiri dari sumber DC 48V, inverter 3 fasa, rangkaian kontrol. Pemasangan inverter 3 fasa ini digunakan untuk mengatur kecepatan motor BLDC dengan dibantu dengan rangkaian kontrol (Naufal, 2019).

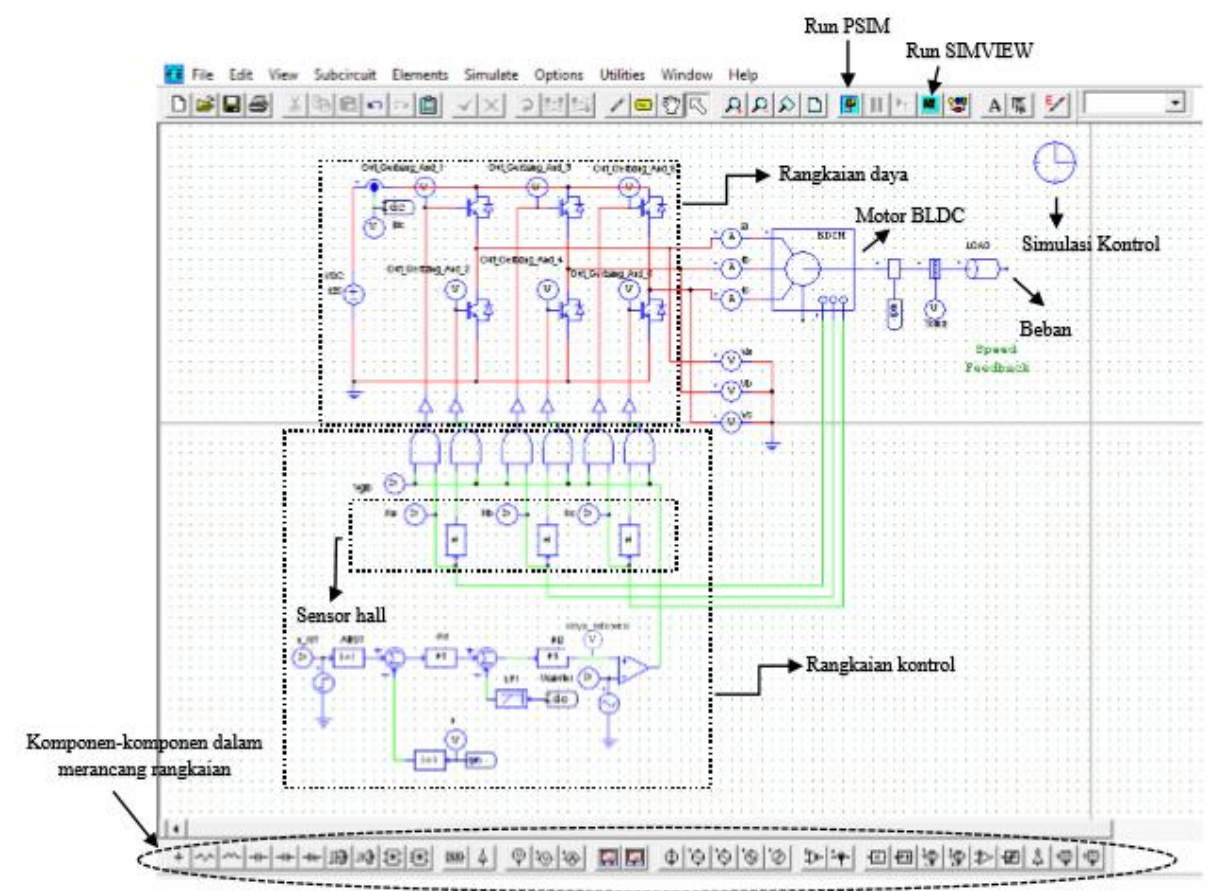

Gambar 3. Sistem Kontrol BLDC Keseluruhan

\subsection{Motor BLDC (Brushless Direct Current)}

Motor BLDC adalah salah satu jenis motor sinkron magnet permanen yang disuplai oleh tegangan DC pada kontrolnya, dan membutuhkan tegangan AC tiga fasa untuk menggerakan pada bagian rotor motornya. Motor BLDC ini menggunakan sistem komutasi elektrik atau biasa disebut electronically comutated motor. Sistem komutasi elektrik ini diartikan sebagai fungsi dari switch electronic. Komutator elektronik ini terdiri dari 6 transistor yang biasanya menggunakan MOSFET atau IGBT dan membutuhkan sinyal atau pulsa penyalaan yang dapat mengaktifkan koil dengan waktu yang telah disesuaikan dengan tepat sehingga dapat menggerakan motor. Dibawah ini akan dijelaskan tentang sistem komutasi motor BLDC.

Motor BLDC ini dapat bekerja ketika stator yang terbuat dari kumparan diberikan arus 3 fasa. Karena arus yang diberikan berupa arus AC fasa, nilai medan magnet dan polarisasi setiap kumparan akan berubah - ubah setiap saat. Sebelum menjelaskan secara terperinci skema cara kerja motor BLDC ini, Perhatikan tabel perubahan komutasi motor BLDC berdasarkan nilai sensor hall yang ditunjukan pada Tabel 1 . 
Tabel 1. Komutasi Motor BLDC

\begin{tabular}{|c|c|c|}
\hline Hall Sensor Value & Phase & Switches \\
\hline 101 & $\mathrm{U}-\mathrm{V}$ & $\mathrm{Q} 1 ; \mathrm{Q} 4$ \\
\hline 001 & $\mathrm{U}-\mathrm{W}$ & $\mathrm{Q} 1 ; \mathrm{Q} 6$ \\
\hline 011 & $\mathrm{~V}-\mathrm{W}$ & $\mathrm{Q} 3 ; \mathrm{Q} 6$ \\
\hline 010 & $\mathrm{~V}-\mathrm{U}$ & $\mathrm{Q} 3 ; \mathrm{Q} 2$ \\
\hline 110 & $\mathrm{~W}-\mathrm{U}$ & $\mathrm{Q} 5 ; \mathrm{Q} 2$ \\
\hline 100 & $\mathrm{~W}-\mathrm{V}$ & $\mathrm{Q} 5 ; \mathrm{Q} 4$ \\
\hline
\end{tabular}

Skema cara kerja motor BLDC adalah sebagai berikut: (Jian, 2014)

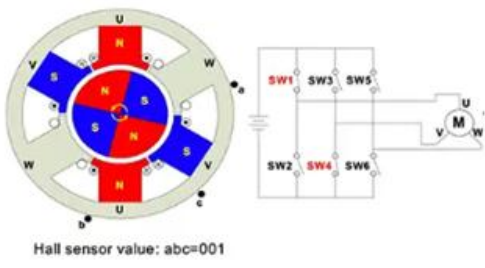

(a)

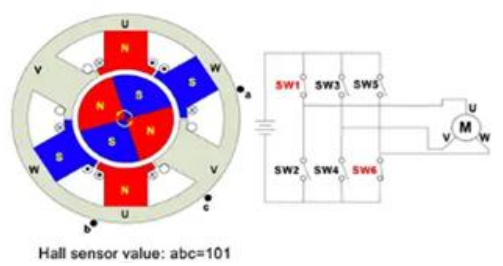

(b)

Gambar 4. Komutasi Motor Step 1 dan Step 2

Perhatikan Tabel 1 dan Gambar 4 (a) menunjukan tahap pertama fasa $U$ dan fasa $V$ dienergized dengan cara switching SW1 dan SW4 secara bersamaan, hal ini akan menciptakan medan magnet yang akan menarik kutub magnet permanen pada rotor. tahap kedua yang aktif untuk switching adalah SW1 dan SW6, fasa U (SW1) tetap di-energized untuk mendorong rotor, dan fasa W di-energized untuk menarik rotor ditunjukan pada Gambar 4 (b). untuk selanjutnya ditunjukan pada Gambar 5.

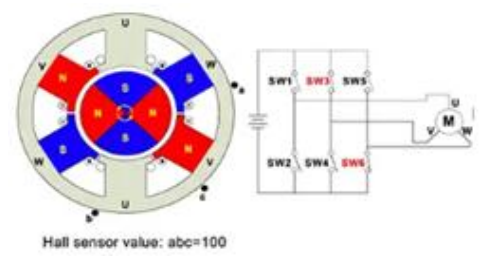

(a)

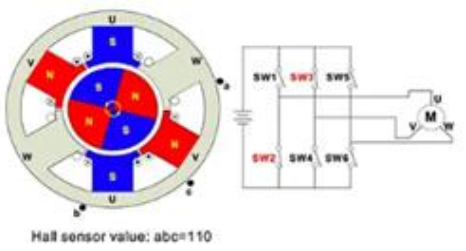

(b)

\section{Gambar 5. Komutasi Motor Step 3 dan Step 4}

Pada Tabel 1 dan Gambar 5, tahap ketiga fasa $V$ dan fasa W di-energized dengan cara switching SW3 dan SW6 secara bersamaan, hal ini akan menciptakan medan magnet yang akan menarik kutub magnet permanen pada rotor ditunjukkan pada Gambar 5 (a). selanjutnya pada tahap 4 yang aktif untuk switching adalah SW3 dan SW2, fasa V (SW3) tetap di-energized untuk mendorong rotor, dan fasa $U$ di-energized untuk menarik rotor ditunjukan pada Gambar 5 (b). 


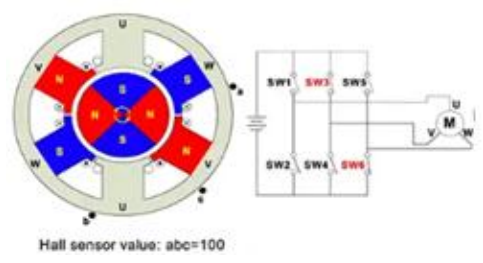

(a)

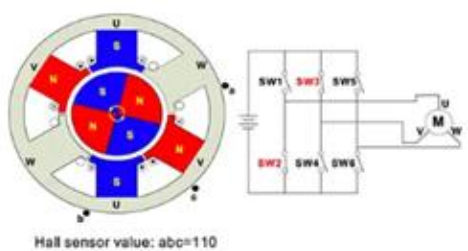

(b)

\section{Gambar 6. Komutasi Motor Step 5 dan Step 6}

Selanjutnya adalah tahap kelima yang ditunjukan pada Gambar 6 (a) fasa W dan fasa U dienergized dengan cara switching SW5 dan SW2 secara bersamaan, hal ini akan menciptakan medan magnet yang akan menarik kutub magnet permanen pada rotor. tahap terakhir untuk switching yang ditunjukan pada Gambar 6 (b) adalah SW5 dan SW4, fasa W (SW5) tetap dienergized untuk mendorong rotor, dan fasa $\mathrm{U}$ di-energized untuk menarik rotor. dengan demikian rotor pada motor BLDC telah melakukan 1 putaran penuh.

Tabel 1 adalah nilai sensor hall yang fungsinya untuk memberikan feedback (umpan balik) pada rangkaian kontrol motor BLDC yang bersifat elektronik yang akan mengendalikan perubahan komutasi pada motor BLDC.

Secara konstruksi yang ditunjukan pada Gambar 7, motor BLDC mendekati seperti konstruksi motor AC sinkron, dimana belitan jangkarnya terletak pada stator dan rotor yang terdiri dari magnet permanen, namun perbedaan antara BLDC dan motor AC sinkron adalah pada backEMF, pada motor AC sinkron magnet permanen berbentuk sinusoidal sedangkan pada motor BLDC berbentuk trapezoidal (Hadyan P, 2016).

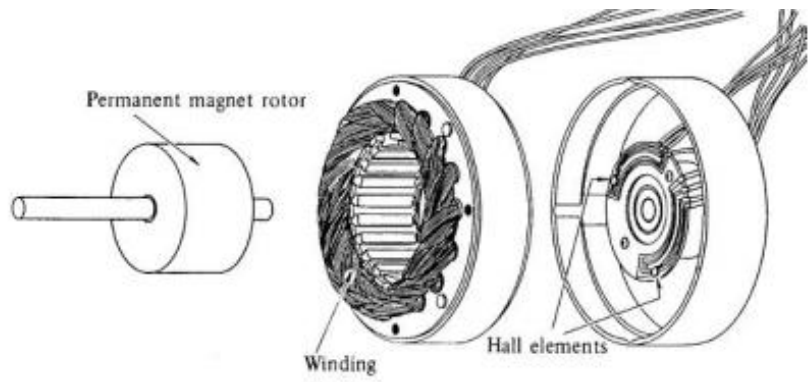

Gambar 7. Konstruksi Motor BLDC

\subsection{Driver Motor BLDC}

Driver merupakan suatu rangkaian dengan sistem elektronik yang berfungsi untuk menggerakkan motor listrik DC, bisa dilihat pada gambar 8. Komponen utama yang digunakan pada driver ini merupakan solid state yang fungsinya sebagai switching atau penyakelaran. Transistor yang digunakan untuk motor listrik DC ini bukan transistor biasa, tetapi menggunakan transistor daya seperti MOSFET, IGBT, dan sebagainya. 


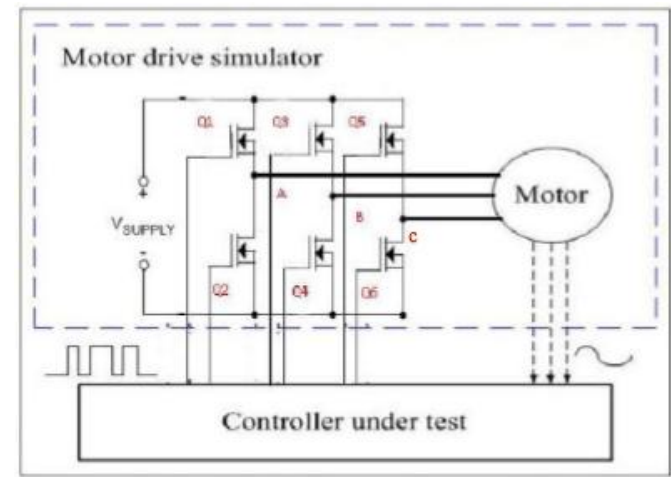

\section{Gambar 8. Rangkaian Driver Motor BLDC}

Cara kerja dari penggerak elektronik daya adalah hanya mengatur waktu penyaklaran pada 6 buah MOSFET secara bergantian sesuai dengan Tabel 1 komutasi motor BLDC. Untuk mengatur waktu penyakelaran tersebut di atur oleh kontroler.

Sistem penggerak ini juga dapat mengubah kecepatan motor dengan dibantu dengan mikrokonrtoler. Mikrokontroler sangat berguna karena memiliki beberapa fitur seperti kecepatan yang lebih cepat, ukuran chip yang kecil, biaya yang murah dan yang terpenting adalah kemudahan untuk troubleshooting. Jadi, dalam perancangan ini mikrokontroler digunakan untuk membangkitkan switching yang dibutuhkan untuk inverter tiga fasa (Adnan, 2016).

\subsection{Perhitungan Hasil Simulasi}

Setalah melakukan simulasi dan mendapatkan nilai yang dibutuhkan, dilakukan perhitungan hasil simulasi untuk menentukan nilai nilai yang dibutuhkan seperti daya input, kecepatan sudut dan daya output dengan persamaan:

Daya input motor BLDC: semakin besar tegangan input (V) dan arus input (I) maka daya input motor BLDCakan semakin besar. Untuk itu digunakan persamaan sebagai berikut: (Halliday, 2011)

$$
\text { Pin }=V_{X} I
$$

$$
\begin{aligned}
& \text { Keterangan : Pin : Daya Input (Watt) } \\
& V: \text { Tegangan Input (Volt) } \\
& I: \text { Arus Input (Ampere) }
\end{aligned}
$$

Setelah mendapat nilai daya input dari perhitungan, selanjutnya menghitung untuk mengetahui nilai kecepatan sudut pada motor BLDC yang nilainya ini digunakan untuk mengetahui daya output.

$$
\omega=2 . \pi \cdot n / 60
$$

$$
\begin{aligned}
\text { Keterangan : } \omega & : \text { Kecepatan Sudut (rad/s) } \\
\mathrm{n} & : \text { Kecepatan Motor BLDC (rpm) }
\end{aligned}
$$

untuk mencari daya output motor diperlukan kecepatan sudut dan kecepatan motor BLDC : (Stephen J, 2015)

$$
\text { Pout }=\omega \times \text { Tload }
$$

Keterangan : Pout : Daya Output (Watt) 
Tload : Torka Beban (Nm)

Besarnya torka mekanik ( $\mathrm{T}$ ) dapat didapatkan dari perkalian antara gaya ( $\mathrm{F}$ ) dengan jari jari rotor (r). sehingga untuk mendapatkan nilai torka mekanik dapat digunakan rumus: (Rezky, 2019)

$$
\begin{array}{rll}
\text { Te F x r } & & \\
\text { Keterangan : } \mathrm{T} & : \text { Torka Mekanik (Nm) } \\
\mathrm{F} & : \text { Gaya }(\mathrm{N}) \\
\mathrm{r} & : \text { Jari - jari }(\mathrm{cm})
\end{array}
$$

Efisiensi adalah perbandingan antara daya output dengan daya input motor BLDC, untuk mencari nilai efisiensi digunakan rumus : (Fariz, 2020)

$$
\eta=(\text { Pout } / \text { Pin }) \times 100 \%
$$

Keterangan : $\eta \quad$ : Efisiensi

\section{HASIL DAN PEMBAHASAN}

\subsection{Skema Simulasi Pengaturan Kecepatan}

Untuk simulasi pada penelitian ini menggunakan software PSIM (power simulator). Di dalam software ini ada beberapa rangkaian yang akan digunakan pada penelitian ini, sehingga tinggal memasukan spesifikasi komponen yang digunakan.

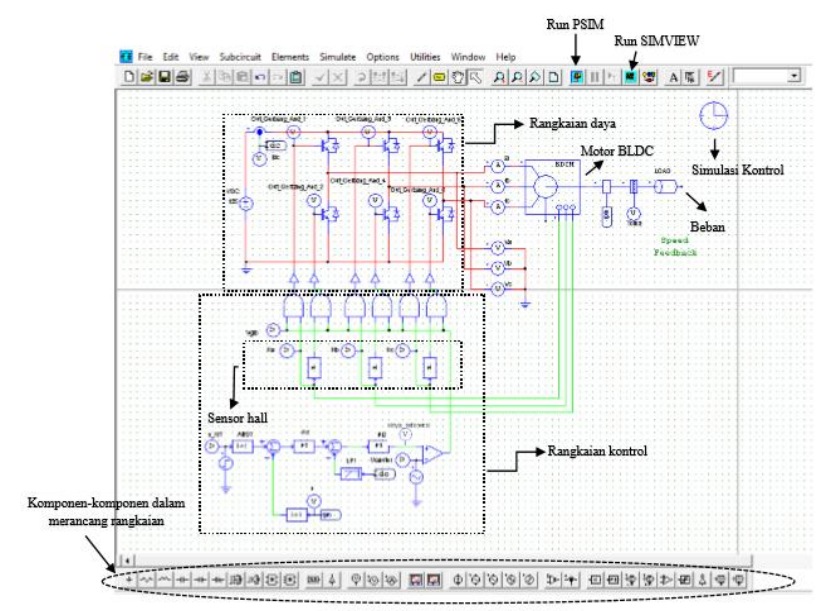

Gambar 9. Skema Simulasi Pengaturan Kecepatan

Rangkaian pada Gambar 9 adalah rangkaian kontrolnya yakni rangkian drive six-step comutation yang ada di software PSIM. Six-step comutation adalah metode pengaturan motor BLDC yang paling sering digunakan karena metode ini sederhana dan mudah untuk diimplementasikan. Dikatakan six-step karena pada satu periode gelombang tebagi menjadi 6 bagian yaitu 2 bagian positif (+), 2 bagian float (0), dan 2 bagian negatif. Gelombang ini digunakan untuk proses komutasi pada motor. Pada penelitian ini, metode six-step comutation akan diterapkan pada inverter 3 fasa sebagai Power Electronic Convertion (PEC). Metode ini akan menjalankan proses switching driver IGBT inverter. Pengaturan kecepatan dapat dilakukan dengan mengubah nilai sinyal referensi dan dilihat perubahan kecepatan terhadap perubahan beban. 
Cara memasukan harga/spesifikasi pada setiap komponen adalah dengan meng-klik dua kali pada komponen tersebut. Lalu untuk menyambungkan setiap komponen menggunakan kawat penghubung. Atur simulasi pada "simulation control" dan pastikan pasang "alat ukur" pada bagian yang akan diukur.

Setelah semua perancangan selesai dilakukan pada PSIM, kemudian program dijalankan dengan meng-klik "Run PSIM", apabila tidak terjadi kesalahan pada rangaian maka persentase akan menujukan angka $100 \%$.

\subsection{Hasil dan Analisis}

Pengujian dilakukan pada beban $0,1,4,8,12,16,20 \mathrm{~N}-\mathrm{m}$ dan $30 \mathrm{~N}-\mathrm{m}$ dengan perubahan kecepatan referensi dari 500, 750, 1000, 1250 dan $1500 \mathrm{rpm} .20 \mathrm{~N}-\mathrm{m}$ adalah beban maksimum untuk motor dengan spesifikasi yang digunakan pada penelitian ini. Beban $30 \mathrm{~N}-$ $\mathrm{m}$ digunakan untuk melihat perubahan yang terjadi ketika motor diberikan beban yang lebih dari kapasitasnya.

a. Hasil Simulasi dan Perhitungan dengan Beban 0,1 Nm

1. Simulasi pada Kecepatan Referensi 500 rpm

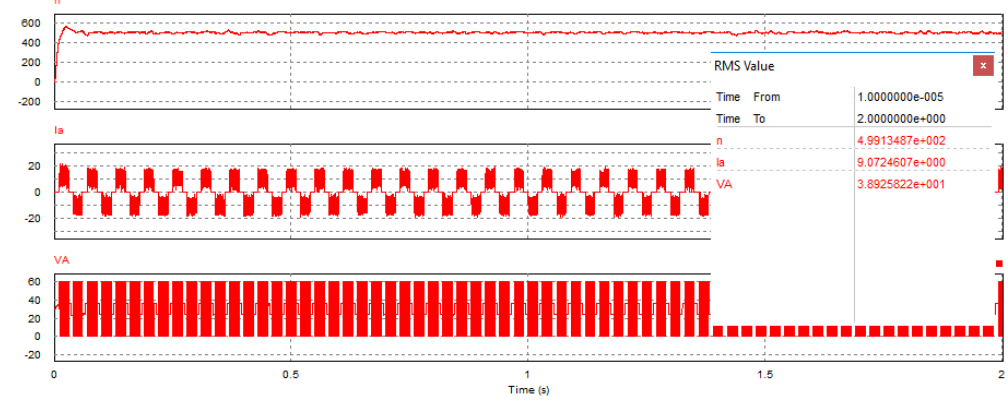

Gambar 10. Hasil Simulasi Pada Kecepatan Referensi 500 rpm

Gambar 10 adalah hasil dari simulasi menggunakan software PSIM pada kecepatan referensi 500 dengan beban 0,1 Nm didapatkan tegangan rms $38.92 \mathrm{~V}$, arus rms 90.72 A dan kecepatan motor berputar sebesar 499.13 rpm.

2. Simulasi pada Kecepatan Referensi 750 rpm

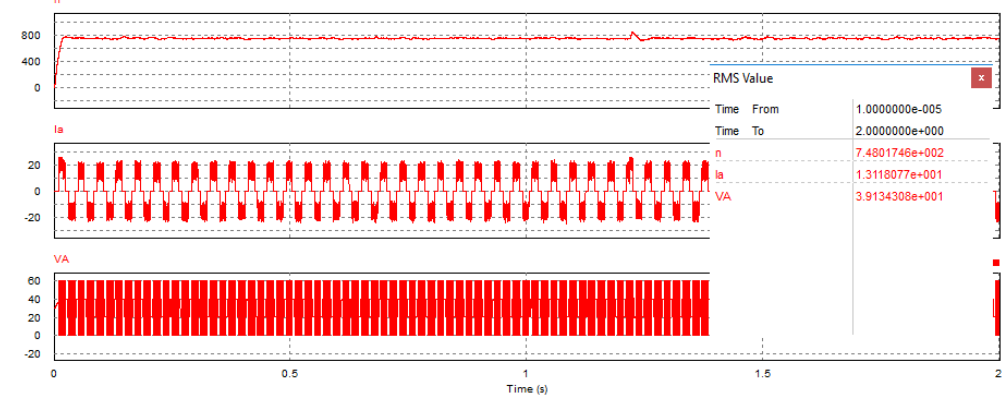

Gambar 11. Hasil Simulasi Pada Kecepatan Referensi 750 rpm

Gambar 11 adalah hasil dari simulasi menggunakan software PSIM pada kecepatan referensi 750 dengan beban 0,1 Nm didapatkan tegangan rms $39.47 \mathrm{~V}$, arus rms 80.25 A dan kecepatan motor berputar sebesar 729.29rpm.

3. Simulasi pada Kecepatan Referensi 1000 rpm 


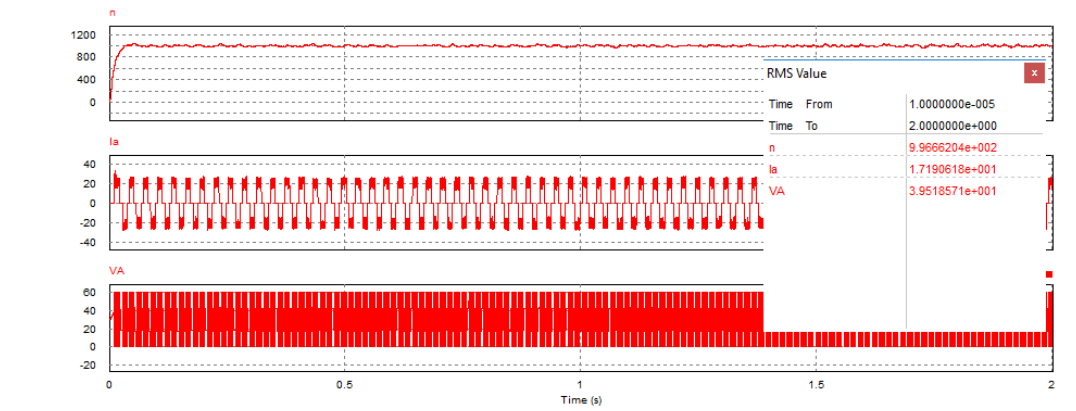

Gambar 12. Hasil Simulasi Pada Kecepatan Referensi 1000 rpm

Gambar 12 adalah hasil dari simulasi menggunakan software PSIM pada kecepatan referensi 1000 dengan beban $0,1 \mathrm{Nm}$ didapatkan tegangan rms $39.75 \mathrm{~V}$, arus rms 84.12 A dan kecepatan motor berputar sebesar 975.00rpm.

4. Simulasi pada Kecepatan Referensi 1250 rpm

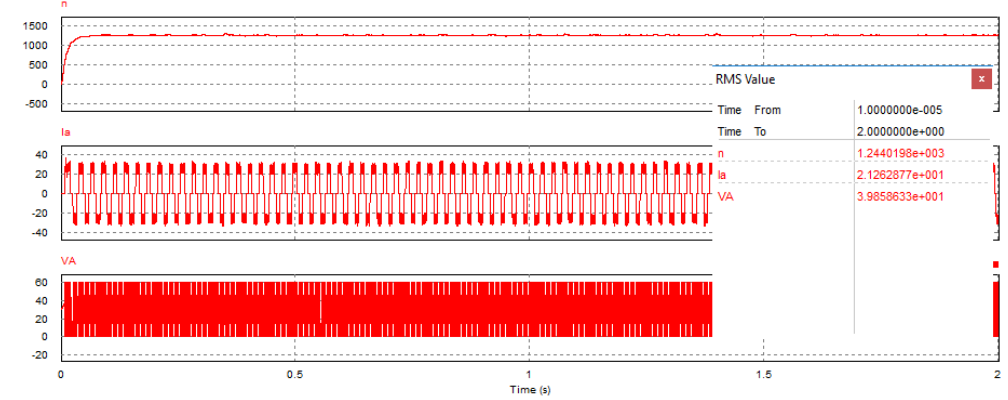

Gambar 13. Hasil Simulasi Pada Kecepatan Referensi 1250 rpm

Gambar 13 adalah hasil dari simulasi menggunakan software PSIM pada kecepatan referensi 1250 dengan beban $0,1 \mathrm{Nm}$ didapatkan tegangan rms $40.08 \mathrm{~V}$, arus rms 88.23 A dan kecepatan motor berputar sebesar 1216.53rpm.

5. Simulasi pada Kecepatan Referensi 1500 rpm

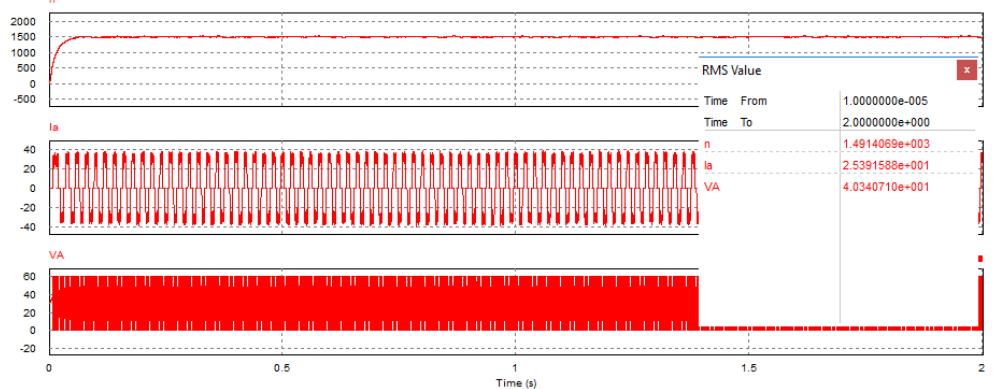

Gambar 14. Hasil Simulasi Pada Kecepatan Referensi 1500 rpm

Gambar 14 adalah hasil dari simulasi menggunakan software PSIM pada kecepatan referensi 1500 dengan beban $0,1 \mathrm{Nm}$ didapatkan tegangan rms $40.56 \mathrm{~V}$, arus rms 91.76 A dan kecepatan motor berputar sebesar 1442.05rpm. 
Tabel 2. Hasil Perhitungan Pada beban 0.1 Nm

\begin{tabular}{|c|c|c|c|c|c|}
\hline Referensi & Pin & Pout & n & Kec. Sudut & Efisiensi \\
\hline 500 & 351.05 & 5.22 & 499.13 & 52.26 & 1.4 \\
\hline 750 & 512.99 & 7.83 & 748.01 & 78.33 & 1.52 \\
\hline 1000 & 679.005 & 10.43 & 996.66 & 104.37 & 1.52 \\
\hline 1250 & 634.611 & 13.027 & 1244.01 & 130.27 & 2.05 \\
\hline 1500 & 1024.23 & 78.135 & 1491.4 & 156.17 & 7.8 \\
\hline
\end{tabular}

b. Hasil Simulasi dan Perhitungan dengan Beban $4 \mathrm{Nm}$

Tabel 3. Hasil Simulasi Pada Beban 4 Nm

\begin{tabular}{|c|c|c|}
\hline Referensi & Vin & Iin \\
\hline 500 & 38.89 & 21.99 \\
\hline 750 & 39.23 & 26.17 \\
\hline 1000 & 39.5 & 30.29 \\
\hline 1250 & 39.95 & 34.41 \\
\hline 1500 & 40.35 & 38.51 \\
\hline
\end{tabular}

Tabel 4. Hasil Perhitungan Pada beban 4 Nm

\begin{tabular}{|c|c|c|c|c|c|}
\hline Referensi & Pin & Pout & n & Kec. Sudut & Efisiensi \\
\hline 500 & 854.8 & 200.16 & 496.97 & 52.04 & 23,41 \\
\hline 750 & 1025.99 & 312.08 & 745.1 & 78.02 & 30.41 \\
\hline 1000 & 1196.06 & 415.56 & 992.14 & 103.89 & 34.74 \\
\hline 1250 & 1374.67 & 519.12 & 1239.37 & 129.78 & 37.67 \\
\hline 1500 & 1553.87 & 622.48 & 1486.1 & 155.62 & 40.06 \\
\hline
\end{tabular}

c. Hasil Simulasi dan Perhitungan dengan Beban $12 \mathrm{Nm}$

Tabel 7. Hasil Simulasi Pada Beban 12 Nm

\begin{tabular}{|c|c|c|}
\hline Referensi & Vin & Iin \\
\hline 500 & 39.09 & 49.05 \\
\hline 750 & 39.25 & 52.94 \\
\hline 1000 & 39.59 & 56.94 \\
\hline 1250 & 40.04 & 61.16 \\
\hline 1500 & 40.48 & 65.45 \\
\hline
\end{tabular}

Tabel 8. Hasil Perhitungan Pada beban 12 Nm

\begin{tabular}{|c|c|c|c|c|c|}
\hline Referensi & Pin & Pout & n & Kec. Sudut & Efisiensi \\
\hline 500 & 1916.48 & 618.36 & 492.16 & 51.53 & 32.26 \\
\hline 750 & 2077.89 & 925.92 & 736.9 & 77.16 & 44.56 \\
\hline 1000 & 2254.25 & 1236 & 983.61 & 103 & 54.28 \\
\hline 1250 & 2447.83 & 1545.12 & 1229.6 & 128.76 & 63.12 \\
\hline 1500 & 2649.41 & 1851.24 & 1473.19 & 154.27 & 69.87 \\
\hline
\end{tabular}


d. Hasil Simulasi dan Perhitungan dengan Beban 20 N-m

Tabel 11. Hasil Simulasi Pada Beban 20 Nm

\begin{tabular}{|c|c|c|}
\hline Referensi & Vin & Iin \\
\hline 500 & 39.5 & 91.25 \\
\hline 750 & 39.45 & 94.08 \\
\hline 1000 & 40 & 98.64 \\
\hline 1250 & 40.47 & 101.52 \\
\hline 1500 & 40.50 & 101.58 \\
\hline
\end{tabular}

Tabel 12. Hasil Perhitungan Pada beban $20 \mathrm{Nm}$

\begin{tabular}{|c|c|c|c|c|c|}
\hline Referensi & Pin & Pout & n & Kec. Sudut & Efisiensi \\
\hline 500 & 2998.86 & 1010.8 & 482.67 & 50.54 & 33.7 \\
\hline 750 & 3167.46 & 1527.4 & 729.29 & 76.37 & 48.22 \\
\hline 1000 & 3167.46 & 2042 & 975 & 102.1 & 64.47 \\
\hline 1250 & 3532.72 & 2547.8 & 1216.53 & 127.34 & 72.12 \\
\hline 1500 & 3719.03 & 3020.2 & 1442.05 & 151.01 & 81.20 \\
\hline
\end{tabular}

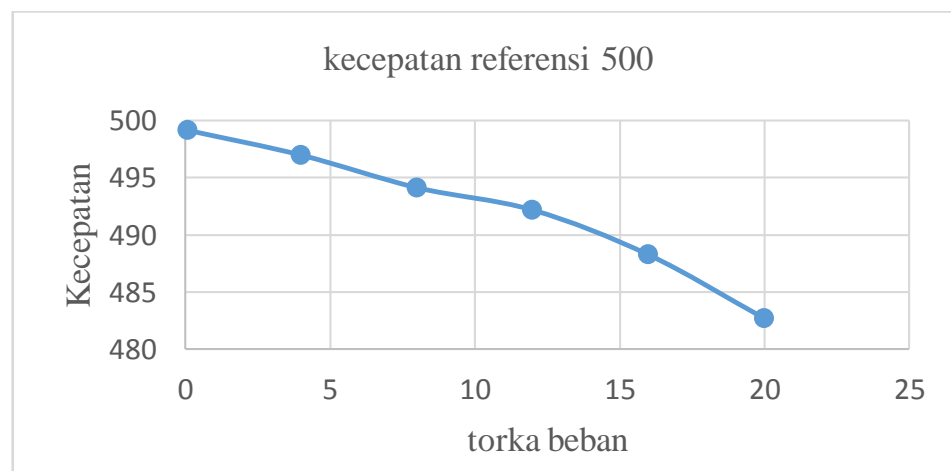

\section{Gambar 15. Grafik Torka Beban Terhadap Kecepatan Pada Sinyal Referensi 500 rpm}

Gambar 15 adalah grafik yang menunjukan simulasi kecepatan motor BLDC diubah- ubah torka bebannya. Pada saat simulasi dengan sinyal referensi 500 dengan beban yang pertama yaitu 0,1 Nm, kecepatan motor BLDC turun menjadi 499,13 rpm atau 99,8\%, pada saat torka beban dinaikan ke $4 \mathrm{Nm}$ kecepatan motor BLDC juga menurun menjadi 496,97 rpm atau $99,4 \%$ dan kecepatan motor BLDC akan terus menurun kecepatannya ketika torka beban ditambah. Dan pada saat torka beban maksimum $20 \mathrm{Nm}$, kecepatan motor BLDC turun menjadi 482,67 rpm atau 96,6 \% dari referensi.

Berdasarkan hasil simulasi pada motor BLDC didapatkan beberapa hasil analisis mengenai hubungan kecepatan terhadap torka yang berubah - ubah dan perubahan efisiensi terhadap perubahan torka beban :

1. Pada simulasi pertama dengan kecepatan referensi 500 dengan torka beban $0,1 \mathrm{Nm}$, nilai kecepatan berada pada 499,13 rpm, arus yang didapat pada torka beban 0,1 Nm adalah 9,07. pada saat beban dinaikan ke $4 \mathrm{Nm}$ nilai kecepatan menurun menjadi 496,97 rpm. Hal tersebut juga juga terjadi untuk beban berukuran lebih besar lainnya kecepatan akan terus turun, bisa dilihat pada Gambar 4.27 dimana jika beban terus dinaikan hingga beban maksimum makan kecepatan motor BLDC akan terus menurun. Berbeda dengan 
arus yang semakin besar kenaikan torka beban, maka nilai arus akan semakin besar dikakrenakan nilai torka beban linier dengan nilai arus, dapat dilihat pada Tabel 4.1.

2. Pada simulasi pada sinyal referensi 750 sampai dengan 1500 dan dengan cara yang sama mengubah - ubah torka beban dari 0,1 Nm sampai dengan $20 \mathrm{Nm}$, dapat dilihat pada Tabel 4.1, bahwa kecepatan motor BLDC akan turun saat torka beban ditambah. begitu juga dengan arus, arus akan semakin besar ketika torka beban ditambah, karena nilai beban torka linear dengan nilai arus.

3. Untuk effisiensi motor BLDC pada Tabel 4.1, dengan torka beban $0,1 \mathrm{Nm}$ pada sinyal referensi 500, efisiensi motor BLDC sangat lah kecil, itu dikarenakan karakter dari motor BLDC itu sendiri, dengan torka beban yang kecil maka efisiensi akan kecil dan akan terus meningkat nilai efisiensinya sampai pada titik torka beban maksimal pada motor BLDC, yang diketahui sebesar $20 \mathrm{Nm}$.

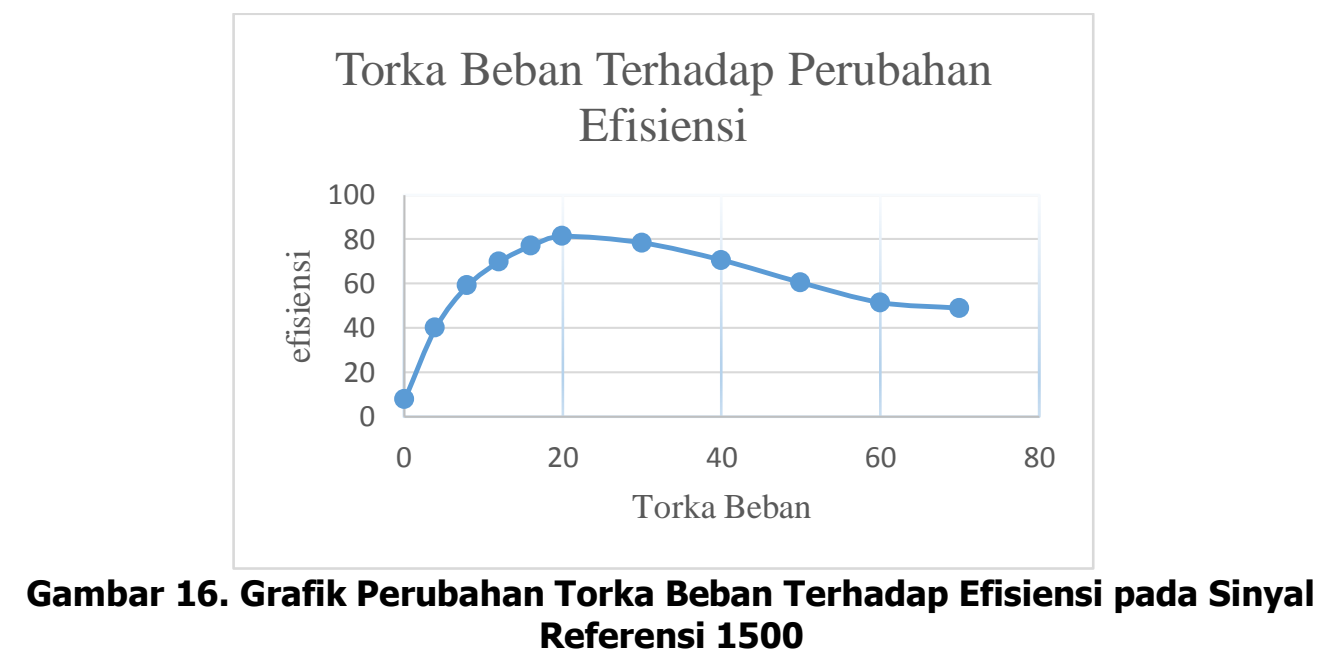

Pada Gambar 16 menunjukan torka beban telah mencapai torka maksimum lalu ditambah 30 $\mathrm{Nm}$ sampai dengan $70 \mathrm{Nm}$, maka efisiensi motor BLDC akan turun. Begitu juga pada sinyal referensi 750, 1000, 1250 dan 1500, ketika beban bertambah maka nilai efisiensi akan naik hingga mencapai titik maksimum pada saat torka beban $20 \mathrm{Nm}$, dan ketika ditambah terus menerus maka efisiensi motor BLDC akan mencapai $0 \%$ efisiensinya.

\section{KESIMPULAN}

Berdasarkan hasil analisis pengaturan kecepatan motor BLDC yang dikerjakan untuk penelitian ini, dapat diambil kesimpulan sebagai berikut:

1. Pada simulasi motor BLDC ini dengan sinyal referensi 1500 dengan torka beban maksimum, kecepatan motor BLDC mengalami penurunan kecepatan menjadi 1442,05 dan pada saat beban diturunkan menjadi $16 \mathrm{Nm}$ kecepatan motor BLDC meningkat menjadi 1465,44 rpm, hasil simulasi ini membuktikan bahwa kecepatan motor BLDC akan turun apabila torka beban yang digunakan terus diperbesar.

2. Motor BLDC dengan spesifikasi yang digunakan pada simulasi dengan speed rating 1500rpm, power rating 3000 ini, bisa diberikan torka beban maksimum sampai $20 \mathrm{Nm}$ dengan efisiensi $81,25 \%$. Ketika motor BLDC ini diberikan beban yang melebihi $20 \mathrm{Nm}$ kecepatan motor BLDC akan turun dan efisiensi motor BLDC juga mengalami penurunan yang hasilnya dapat dilihat pada Gambar 16. 
3. Waktu untuk 1 kali putaran motor BLDC pada saat torka beban 0,1 adalah 0,026 detik, dan pada saat simulasi dengan torka beban 20, motor BLDC memerlukan waktu 0,029 detik. Hasil simulasi ini membuktikan bahwa pada saat motor BLDC diberikan torka beban yang kecil maka putaran motor BLDC akan semakin cepat karena hanya memerlukan waktu 0,026 detik untuk satu kali putaran, di bandingkan dengan di berikan torka beban $20 \mathrm{Nm}$ yang membutuhkan waktu 0,029 untuk satu kali putarannya.

4. Pada pengaturan kecepatan, sinyal referensi diubah pada bagian rangkian kontrol dengan nilai 500, 750, 1000, 1250 dan 1500. Pada pengaturan kecepatan ini dilihat apakah rangkaian kontrol berjalan dengan baik atau tidak. Dan hasilnya dapat dilihat pada Gambar 10 hingga 14, dimana kecepatan motor BLDC akan mengikuti sebagaimana yang di inputkan pada rangkaian kontrol.

\section{UCAPAN TERIMA KASIH}

Terima kasih kepada Jurusan Teknik Elektro Itenas Bandung karena telah mengizinkan penulis mengerjakan penelitian ini di Lab Teknik Energi Elektrik, Terima kasih juga untuk Pak Syahrial S.T., M.T selaku pembimbing yang telah membantu penulis untuk menyelesaikan penelitian ini.

\section{DAFTAR RUJUKAN}

Adnan, M. M. (2016). Implementation of a Three Phase Inverter for BLDC Motor Drive. 9th International Conference on Electrical and Computer Engineering (p. 337). Dhaka, Bangladesh: IEEE.

Ali,

M.

(2021).

Retrieved

from

www.wordpress.com:

https://muhal.wordpress.com/2011/09/30/simulasi-rangkaian-elektronika-dayadengan-psim/

Azzumar, M. (2012). Pemodelan dan Desain Kendali Sistem Aktuator Kendali Sirip Berbasis Brushless Motor DC. Depok: Universitas Indonesia.

Chandra R. S. Y. (2018). Analisa Pembebanan pada Motor Brushless DC (BLDC). SNIKO (p. 277). Bandung: Institut Teknologi Bandung.

Djodi, A. (2012, November minggu ). Motor Brushless DC Tiga Fasa - Satu Kutub. ORBITH, 32.

Eclesia I, F. J. (2013). Brushless Motor DC. Jurnal Elektromagnetika - Universitas Pancasila.

Fariz, M. A. (2020). Rancang Bangun Motor BLDC Axial Flux Menggunakan Dua Kawat Email Pada Lilitan Kumparan Stator. Jurnal Arus Elektro (JEAI).

Gifary, H. (2017). Rancang bangun motor bldc tiga fasa sensorless. Jember: Universitas jember .

Hadyan P, P. H. (2016). Perbaikan Faktor Daya Menggunakan Cuk Konverter pada Pengaturan Kecepatan Motor Brushless DC. Jurnal Teknik ITS, B156. 
Halliday, D. D. (2011). Physics 9th Edition . America: John Wiley \& Sons, Inc. Jian, Z. Y. (2014). Brushless DC Motor Fundamental Application Node. MPS Module.

Naufal, M. D. (2019). Pengaturan Kecepatan Motor Brushless DC (Direct Current) Menggunakan Cuk Converter. Jurnal Teknik Elektro dan Komputer Triac, 34 - 39.

Rezky, M. (2019). Rancang Bangun Motor BLDC Tiga Fasa Sensorless dengan Tipe Konstruksi Out-Runneer. Jember : Universitas Jember.

Stephen J, C. (2015). Electric Machinery Fundamentals 5th Edition. Australia: Raghothaman Srinivasan. 